\title{
Influencing Factors of Load Characteristics of Electric Vehicles
}

\author{
Rongjun Chen ${ }^{1, *}$, Dezhi $\mathrm{Li}^{2}$ and Yongxiu $\mathrm{He}^{1}$ \\ ${ }^{1}$ School of Economics and Management, North China Electric Power University, Zhu Xin Zhuang, Bei Nong Road No.2, \\ Changping District, Beijing, China \\ ${ }^{2}$ China Electric Power Research Institute, Xiaoying East Road No.15, Qinghe, Haidian District, Beijing, China \\ *Corresponding author
}

\begin{abstract}
As the gradual improvement of environmental awareness in recent years, electric vehicles (EV) have made great progress. The paper first analyses the influencing factors of the electric vehicle's load characteristics, and then selects three load characteristic index of electric vehicle, divides the electric car according to different users into the following categories: electric taxi, electric bus and household electric car. The factors influencing the load characteristics of the electric vehicle are summarized, and the influencing factors are analyzed qualitatively based on economic, policy, social and other factors. At last, the factors that influence the peak and off-peak load gap and the average load of electric vehicle are pointed out respectively.
\end{abstract}

Keywords-component; load characteristic; EV; generalized load; influence factors

\section{INTRODUCTION}

As the fast development of smart grid, the proportion of generalized load in the grid has increased gradually. Generalized load refers to part of the grid in the receiver power system that consists of a number of static load, dynamic load, transmission network with low voltage, generator with small capacity and other elements [1]. The electric vehicle (EV) can be seen as a kind of dynamic load of the generalized load. EV can improve the operation economy of power system and ensure the security through demand side response and the interaction with grid. With the development of electric vehicle technology in the future, it can also be used to supply power to the grid.

As a result of the national policy which aims at promoting the production and sales of electric vehicles in China, the EV market has achieved rapid growth, thus China has become the world's second largest EV market. According to the China Association of Automobile Manufacturers statistics, in 2016 Chines produced 517000 renewable energy vehicle, an increase of $51.7 \%$ over the same period last year. Among them, pure electric vehicle production were 417000 , increased by $63.9 \%$ compared with the same period last year, plug-in hybrid car production were 99 thousand, which has increased by $15.7 \%$.

In the situation of rapid development of electric vehicles, the analysis of the load characteristics of electric vehicles is conducive to the optimization of power system design, to achieve optimal power grid scheduling, and to produce a positive impact on the safety and stability of the grid, so this article launched the study on load characteristics of electric vehicles, and then research it by decomposing its influencing factors.

\section{ANALYSIS OF LOAD CHARACTERISTICS OF ELECTRIC VEHICLE}

\section{A. Index of Load Characteristic}

Load characteristics can be used to illustrate the load in the grid, usually in the form of data or curves. The load characteristic index classification is shown in Table 1.

TABLE I. CLASSIFICATION OF LOAD CHARACTERISTICS

\begin{tabular}{|c|c|c|c|}
\hline $\begin{array}{c}\text { Load } \\
\text { character } \\
\text { istics }\end{array}$ & $\begin{array}{c}\text { Daily load } \\
\text { characteristi } \\
\text { cs }\end{array}$ & $\begin{array}{l}\text { Monthly load } \\
\text { characteristics }\end{array}$ & $\begin{array}{l}\text { Annual load } \\
\text { characteristics }\end{array}$ \\
\hline $\begin{array}{l}\text { Descriptiv } \\
\text { e } \\
\text { indicators }\end{array}$ & $\begin{array}{c}\text { Day } \\
\text { maximum and } \\
\text { minimum } \\
\text { load, daily } \\
\text { average load, } \\
\text { daily peak } \\
\text { difference }\end{array}$ & $\begin{array}{c}\text { Month maximum } \\
\text { and minimum } \\
\text { load, monthly } \\
\text { average load }\end{array}$ & $\begin{array}{c}\text { Annual maximum } \\
\text { and minimum } \\
\text { load, the largest } \\
\text { peak and valley } \\
\text { difference }\end{array}$ \\
\hline $\begin{array}{l}\text { Comparati } \\
\text { ve } \\
\text { indicators }\end{array}$ & $\begin{array}{lr}\text { Daily load } & \text { loaily } \\
\text { rate, } & \text { dainimum } \\
\text { minimur } & \\
\text { load rate, } \\
\text { daily } \\
\text { rate }\end{array}$ & $\begin{array}{l}\text { Monthly average } \\
\text { daily load rate, } \\
\text { monthly load rate, } \\
\text { monthly minimum } \\
\text { load rate }\end{array}$ & $\begin{array}{c}\text { Annual average } \\
\text { daily load rate, } \\
\text { annual average } \\
\text { monthly load rate, } \\
\text { annual maximum } \\
\text { peak-valley rate, } \\
\text { annual load rate, } \\
\text { annual maximum } \\
\text { load utilization } \\
\text { hours }\end{array}$ \\
\hline $\begin{array}{l}\text { Curve } \\
\text { indicators }\end{array}$ & $\begin{array}{l}\text { Daily load } \\
\text { curve }\end{array}$ & $\begin{array}{l}\text { Monthly load } \\
\text { curve }\end{array}$ & Annual load curve \\
\hline
\end{tabular}

Due to the large number of load characteristic indexes and in order to fully consider the load features of electric vehicles, this paper selects three indicators to describe the characteristics of electric vehicle load, respectively are the average load, peak and off-peak load gap and the load curve.

Among them, the average load can reflect the overall level of regional electric vehicle load, peak and off-peak load gap helps to show the load gap in a day, the load curve illustrates a period of time the specific load changes [1]. 


\section{B. Load Characteristics of Different Users of EV}

Usually, the purposes of different users using the electric vehicles are different, thus the charging time and charging methods are various.

Therefore, this article divides the users of electric vehicles into three categories, namely the electric buses, electric taxis, home use electric car, and then the load characteristics and load curve of EV are analyzed based on the above classification.

Home use electric car is generally charging after $6 \mathrm{pm}$, adopting slow charging or conventional charging mode, while using fast charging mode with low load level at noon. Due to the higher charging time requirements of electric taxies, they generally use fast charging mode in the morning and noon. Similarly, electric bus cars apply the conventional charging mode at late night and switch to fast charging mode in the noon to supply energy to the battery [2].

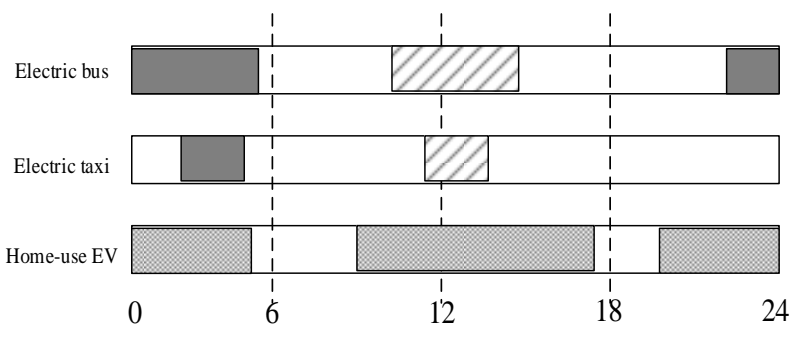

Conventional charging $D$ Fast charging

FIGURE I. CHARGING TIME AND MODES OF DIFFERENT USERS

The load curve of different users in a day is shown in Figure 2.

The peak load period of home use electric cars is around 18 : 00-24: 00, while the off-peak period usually lies in the day, especially 5: 00-8: 00. Different from the home use electric cars, electric taxi load exhibits several off-peak periods, which often appears is the commute peak period. As a result of a fixed dispatching mode, the electric bus usually charges at night and occasionally charges fast during the noon, so the load at night is relatively large $[3,4,5]$.
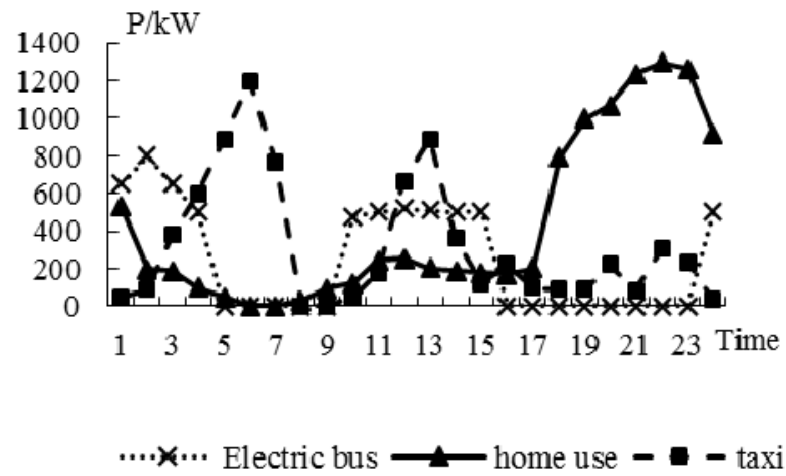

FIGURE II. LOAD CURVES OF DIFFERENT ELECTRIC VEHICLES

\section{FACTORS THAT INFLUENCE THE LOAD CHARACTERISTICS OF ELECTRIC VEHICLE}

By analyzing the load characteristics of various types of electric vehicles, load of EV is mainly affected by economic, policy, social and other aspects.

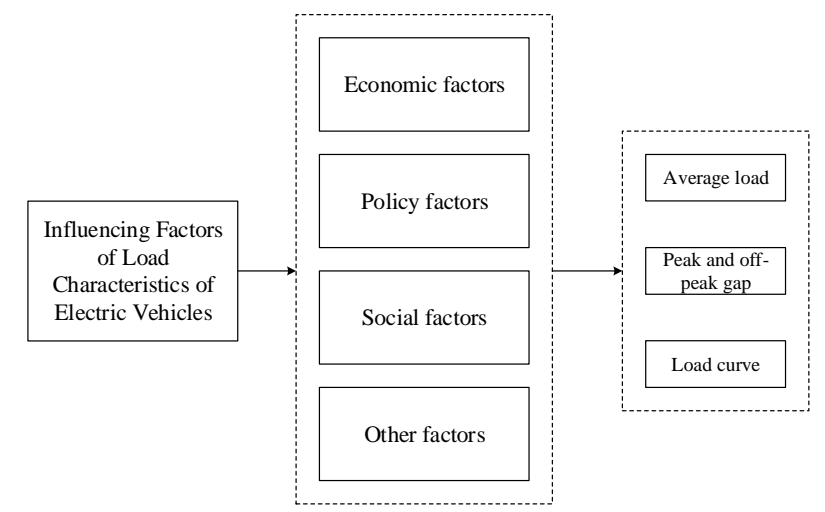

FIGURE III. INFLUENCING FACTORS OF ELECTRIC VEHICLE LOAD CHARACTERISTICS

\section{A. Economic Factors}

\section{(1) Battery cost}

Compared to the traditional car, due to the high cost of electric cars' battery and the entry barrier such as manufacturing technology, the total cost of making an electric car is high. For example, battery cost counts more than a half of total cost in manufacturing an electric car with normal performance. If the manufacturing technology realizes substantive leap in the future, the average load of electric vehicles is very considerable.

\section{(2) Per-capita spending level}

The level of per-capita spending directly determines the sales volume and ownership of electric vehicles, which has a high positive correlation with electric vehicle charging load. However, due to the relatively high sale price of electric vehicles, the current sales of electric vehicles are mainly promoted by the government and the consumers' initiative to buy it is low, which also led to a lower electric car load rate.

\section{B. Policy Factors}

\section{(1) Subsidies of electric car}

Since the implementation of subsidy policy to new energy vehicles in China in 2010, the amount of subsidies has declined year by year and the subsidy condition of the EV has increased year by year at the same time. Besides that, the fuel consumption limit of automobile companies continue to decline, which indicates that the government hopes to promote the development of new energy vehicles through market forces. To a certain extent, the weakening of subsidy policy may be detrimental to the promotion of electric vehicles, reducing the average load of future electric vehicles.

\section{(2) Price policy}

The load of electric vehicles could be adjusted by the implementation of the peak and off-peak electricity price or 
signing agreement with the users. The implementation of electric vehicle electricity price policy helps to guide and control the electric vehicle charging behavior orderly by avoiding the peak load period of the grid load, reducing the impact of the load on the grid and unnecessary power generation and power grid construction. The purpose of peak shaving and valley filling can be realized as long as the peak and off-peak load gap is reduced [6].

\section{Social Factors}

\section{(1) Urbanization rate}

The urbanization rate is able to reflect the level of development in a region. Chinese EVs are developed from regions with higher urbanization rate, people there are more acceptable to new things and the demand of EVs there is high. Urbanization process can increase the needs of electric vehicles, enhancing the overall load of electric vehicles in the end.

\section{(2) Charging pile construction}

The construction of the charging pile is related to the popularity of the electric car.

According to statistics, the number of the charging stations in China has increased from 76 in 2010 to 3600 in 2015, and the amount of the public charging pile has increased from 1122 to 49000. In addition to the public charging pile, the number of private charging pile is close to 50000 and the commercial charging pile (for buses, logistics vehicles, enterprises and public institutions) is about 50000-60000 in 2015.

Besides, the "electric vehicle charging infrastructure planning" put forward by the National Energy Board show that the pile will reach 4.5 million by 2020 and the electric car charging load will increase followed by the construction of piles.

\section{Other Factors}

\section{(1) Temperature}

The additional energy consumption, battery performance, traffic conditions and other aspects of electric vehicles will be affected by ambient temperature.

The additional energy consumption of the electric vehicle refers to the energy consumption except the electric motor, such as the energy consumption of the air conditioner, the battery insulation system, the lamp and the mobile equipment. Figure 4 shows how the additional energy consumption changes as the ambient temperature changes. It can be seen from the curve that the more the temperature drops, the greater the increase in energy consumption.

Figure 4 shows how the additional energy consumption changes as the ambient temperature changes. It can be seen from the curve that the more the temperature drops, the greater the increase in energy consumption.

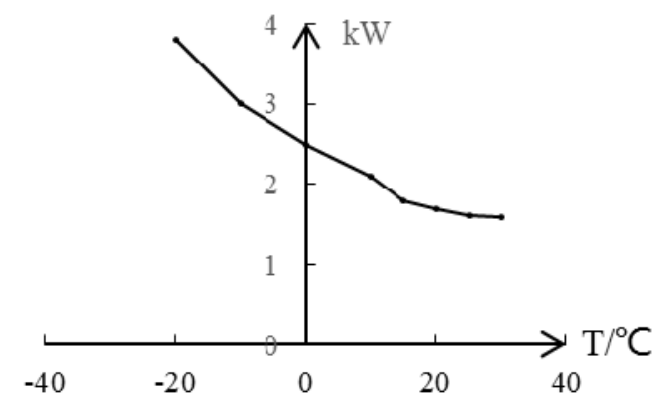

FIGURE IV. THE RELATIONSHIP BETWEEN THE ADDITIONAL ENERGY CONSUMPTION AND THE TEMPERATURE OF AN ELECTRIC VEHICLE

The drop of temperature will also affect the battery performance, thereby reducing the maximum mileage of electric vehicles. So if the temperature is low, the electric car charging frequency should be speeded up, which increases the electric vehicle load.

In addition, different traffic conditions can produce different impacts on electric vehicle. In the case of $-20{ }^{\circ} \mathrm{C}$ temperature, electric vehicles need to increase the power by $10 \%$ to maintain the same driving state compared to $23^{\circ} \mathrm{C}$ [7].

\section{(2) Users’ habits}

Different user groups have different power habits. The charging time and charging modes will have an impact on the electric vehicle load, especially on the peak and off-peak gap. For instance, due to the need of rolling on time, the charging load of electric buses is relatively fixed, while the home use car will be arranged according to travel conditions.

In addition, the user habits can directly affect the whole charge time and charging frequency by influencing the electric vehicle daily mileage. Day mileage of electric taxi is the largest among all users, which is about $400 \mathrm{~km}$, followed by electric buses, and home electric vehicles is the shortest, which is about $40 \mathrm{~km}$.

\section{CONCLUSION}

This paper analyzes the charging load characteristics and charging and discharging habit of each type of electric vehicle users. Then puts forward the factors that affect the load characteristics of electric vehicles. For instance, price policy, user habits, temperature and other factors will affect the peak and off-peak gap of electric vehicle load, and economic factors, social factors, subsidies and other policies will affect the development of electric vehicles and then have an effect on the growth rate of electric vehicle load.

\section{REFERENCES}

[1] H.C. Luo, Z.C. Hu, H.C. Zhang, "Effects of Ambient Temperature on Charging Load of Electric Vehicle, ” Electric Power Construction, vol. 36, pp. 69-74, 2015.

[2] C.B. Li, F. Qu, X.N. Wang, et al. "Analysis of Load Characteristics of Power System Based on Fuzzy Clustering, "Journal of Zhengzhou University (Engineering Science Edition), vol.31, pp.107-110, 2010. 
[3] Y.F. Li, M. Huang, W.G. Zhang, "Electric taxi rental charging method, ” Power System Automation, vol.38, pp. 55-60, 2014.

[4] M.X. Zhang, T. Zhuang, "Measurement and Analysis of Charging Load of Electric Vehicle in Residential Area," Power Demand Side Management, vol.14, pp. 44-46, 2012.

[5] Q.S. Li, X.N. Xiao, S. Tao, X.Y. Zhang. "Analysis of EV Charging Load and Its Applications in Distribution Systems, " Transactions of China Electrotechnical Society. vol.28, pp. 30-35, 2013.

[6] S.Y. Ge, H. Huang, H. Liu. "Optimization of peak - valley price for electric vehicle in orderly charging, " Power System Protection and Control, vol. 40, pp.1-5, 2012.

[7] J. Laurikko, R. Granstrom, A. Haakana. "Realistic estimates of EV range based on extensive laboratory and field tests in Nordic climate conditions, ” IEEE. Electric Vehicle Symposium and Exhibition, pp.1-12, 2013 